\title{
Dislokasi Identitas Agama dan Budaya Perkotaan: Perkembangan Kampung Wisata di Kota Yogyakarta
}

\author{
Zaenuddin Hudi Prasojo, ${ }^{1 *}$ Muhammad Arifin, ${ }^{2}$ Irwan Abdullah ${ }^{3}$ \\ ${ }^{1}$ Institut Agama Islam Negeri Pontianak, ${ }^{2}$ Fakultas Ilmu Sosial dan Ilmu Politik, \\ Universitas Mulawarman, Samarinda, ${ }^{3}$ Departemen Antropologi, Fakultas Ilmu \\ Budaya, Universitas Gadjah Mada, Yogyakarta - Indonesia
}

\begin{abstract}
Since the early 20th century, villages in the city of Yogyakarta has started to become villages of tourism following the government promoting tourism in the region. Originally carrying local and cultural identities, those villages appear to be touristic, accommodating the needs of the visitors. This work attempts to explore how this social phenomenon happening to two urban villages within the city namely Kampung Kauman and Kampung Prawirotaman. It focuses on explaining how the villagers actively play their roles in the neighborhood in social and cultural processes within the new environment and physical space. The appropriate data found in the field is analyzed accordingly to the research questions by employing a qualitative approach. The work suggests that cultural identity has changed in these two urban villages as a result of the influence of external values promoting the redefinition and redesign of public and social space. Besides, it also finds that delegitimization of the identity of Kampung and communality dislocation has occurred due to tourism purposes. The new formulation of the Kampung does not only reflect the emergence of new ideology and tradition but also stimulate resistance, conflict, and negotiation. This study recommends the importance of mentoring programs from the strategic stakeholders for better space and cultural transformation leading to the prevention of the damage of local wisdom basis within urban communities.
\end{abstract}

Sejak awal abad ke-20 kampung-kampung di Yogyakarta menjadi kampung wisata, sejalan dengan giatnya usaha pemerintah menguatkan sektor tersebut. Kampung yang semula memiliki identitas lokal kultural berubah menjadi kampung turistik yang ditata sesuai dengan kebutuhan pengunjung. Tulisan ini mengkaji pengalaman perubahan yang terjadi pada dua kampung yang terletak di dalam kota (kampung kota), yaitu Kampung Kauman dan Kampung Prawirotaman. Penelitian dititikberartkan pada usaha menjawab bagaimana manusia menjalankan perannya secara aktif dalam suatu lingkungan dan ruang fisik dalam suatu proses sosial budaya. Dengan menggunakan metode kualitatif, data-data yang dihasilkan dianalisis untuk menjawab pertanyaan-pertanyaan penelitian yang diajukan. Diasumsikan bahwa identitas budaya berubah di kedua kampung tersebut sejalan dengan masuknya pengaruh luar yang menyebabkan penataan ulang ruang fisik dan ruang sosial. Hasil penelitian menunjukkan terjadinya deligitimasi identitas kampung dan dislokasi komunalitas akibat dari penataan kampung dalam rangka tujuan wisata. Kampung yang terbentuk tidak hanya merefleksikan hadirnya ideologi dan tradisi baru, tetapi juga merefleksikan resistensi, konflik dan negosiasi yang terjadi dalam ruang kampung yang baru. Tulisan ini menyarankan perlunya pendampingan pihak-pihak terkait (stakeholders) dalam transformasi ruang dan kebudayaan sehingga dapat menghindari hancurnya basis-basis kearifan dalam komunitas kota.

Keywords: tourism village; cultural identity; contested space; Yogyakarta

*Korespondensi Penulis: Zaenuddin Hudi Prasojo (zaestain@yahoo.com), Institut Agama Islam Negeri Pontianak, Jl. Letjend. Suprapto No. 19 Pontianak, Kalimantan Barat 78122. 


\section{Pendahuluan}

Pada sepuluh tahun terakhir ini, kampungkampung di Yogyakarta tumbuh menjadi pusatpusat wisata. Kampung mengalami desain ulang dan dilengkapi dengan fasilitas fisik yang sejalan dengan kebutuhan pariwisata. Perubahan lingkungan fisik ini merupakan dasar penting bagi perubahan-perubahan dalam aspek sosial dan kebudayaan. Ruang-ruang di wilayah Yogyakarta mengalami proses reproduksi yang didasarkan pada latar belakang historis dan sosiologis. Tugu Yogyakarta, candi, makam raja, atau gunung dan pantai, tidak hanya ada dan terkenal dengan sendirinya, akan tetapi direproduksi sebagai simbol baru sejalan dengan kebutuhan masyarakat yang terus berubah.

Yogyakarta dikunjungi oleh orang dari luar tidak hanya karena keramahtamahan, atau karena sebagai kota pendidikan sebagaimana banyak dikenal dan dipersepsikan banyak orang selama ini, tetapi juga karena menyimpan banyak kenangan sejarah dan pernak-pernik budaya. Tidak terkecuali Kampung Prawirotaman yang dikenal sebagai Kampung Turis atau Kampung Bule dan Kampung Kauman yang dikenal sebagai Kampung Islam atau Kampung Muhammadiyah. Ini dua contoh kampung kota di Yogyakarta dikenal dan konstruksikan yang menjadi objek kajian dalam tulisan ini.

Secara teoritis, kampung biasanya dimaknai sebagai sebuah pemukiman, namun tidak hanya sekedar nama atau sebutan bagi tempat bermukimnya sekelompok masyarakat atau komunitas. Kampung telah menjadi kategori sosial untuk membedakan suatu komunitas berdasarkan kategori ruang fisik tertentu. Salah satunya kampung menunjuk pada pemukiman yang di- konotasikan dengan kehidupan tradisional dalam suatu lingkungan tertentu (Sumintarsih dan Andrianto 2014: 3-4). Jika permukiman dengan kategori tersebut berada di lingkungan kota, maka ia disebut sebagai "kampung kota" (urban villages). Funo Yamamoto dan Silas, sebagaimana dikutip Hutama (2016) mengemukakan bahwa bentuk unik dari pemukiman informal perkotaan dalam bahasa Indonesia disebut sebagai "kampung urban" atau kampung saja. Kampung yang di dalam kawasan perkotaan kriterianya cenderung bersifat homogen. Para pemukim biasanya berasal dari desa dan tetap bertahan di kawasan perkotaan untuk mencari peluang kerja.

Di Yogyakarta, kata "kampung" mencakup ide bagi mayoritas penghuni kota yang sering disebut "wong cilik" atau mereka menyebut dirinya sebagai orang kampung (Sullivan 1986: 70). Sebagai orang kampung yang tinggal di kawasan perkotaan dengan ciri ciri tertentu serta tradisi dan kehidupan sosial ekonomi mereka yang membedakan dengan kelompok lain mengindikasikan bahwa dalam kehiduapn sosial perkotaan terdapat berbagai budaya atau sub-budaya urban. Masing-masing dari budaya urban ini menunjukkan dan mempertahankan eksistensinya masing-masing dalam ruang-ruang sosial dan ruang fisik perkotaan, sebagaimana ditunjukkan oleh komunitas kampung urban di Kampung Kauman dan Kampung Prawirotaman di Kota Yogyakarta.

Kampung Kauman dan Kampung Prawirotaman memiliki relasi historis dengan perkembangan Keraton Yogyakarta, meskipun keduanya berbeda konteks dan relasi struktur sosialnya. Kedua kampung ini pernah menjadi sentra industri batik terkenal di Yogyakarta. Kedua kampung ini memiliki cara yang berbeda 
dalam merespons perubahan dan pasang surut industri batik (Triatmodjo 2012; Utomo 2019). Kampung Kauman, maupun Kampung Prawirotaman, berusaha mengembangkan diri menjadi kampung tujuan pariwisata di Kota Yogyakarta (Depari 2012; Sativa 2012; Sumintarsih dan Andrianto 2014; Utami dan Haryanto 2015). Kedua kampung ini dapat merepresentasi kampung-kampung di Yogyakarta, khususnya menyangkut sejarah dalam hubungannya dengan kraton, struktur sosial, maupun kontekstualisasi kampung terhadap perubahan eksternal yang terjadi. Sebagai kampung yang berada dalam struktur dan sistem administrasi kota, Kauman maupun Prawirotaman dapat mereprsentasikan berbagai simbol dan ikon Kota Yogyakarta yang berbeda antara satu dengan yang lainnya.

Dalam konteks ini tepat apa yang dikemukakan oleh Peter J. M. Nas, Marlies de Groot and Michelle Schut (2011:9) bahwa "urban symbolism expresses itself through different phenomena, such as the layout of a city, architecture, statues, street and place names, poems, as well as rituals, festivals, and processions; another strand consists of myths, novels, films, poetry, rap, music, songs, and websites, all of which can be called symbol bearers."

Simbol-simbol tersebut dapat berupa benda material, perbincangan, tanda-tanda dan perilaku sosial. Simbol-simbol yang dimaksudkan dapat pula merepresentsikan sebuah identitas, atributatribut atau ragam makna dan budaya yang mencirikan dan mereprsentasikan kelompok urban tertentu di dalam Kota Yogyakarta. Oleh karena itu, tepat apa yang disarankan oleh Hill (1999) bahwa untuk melakukan berbagai kajian atau pengembangan "civic culture", harus dibaca dengan dua cara, yaitu budaya dilihat sebagai suatu teks (as a text) dan sebagai seperangkat aturan yang mengatur masyarakatnya (as an instrument of social control). Teks oleh Hill adalah beragam wacana dan perbincangan tentang makna kota, arsitektur, tentang peradaban dan berbagai infrastruktur fisik kota yang ada. Adapun yang disebut sebagai seperangkat kontrol sosial adalah pengaturan dalam relasi struktur kelas sosial, kekuasaan sosial dan politik, dan akses capital (Hill 1999).

Berbeda dengan Hill menyarakan dua cara dalam memandang fenomena budaya masyarakat civil, Deborah Stevenson (2003:6) melihat begitu banyaknya isu-isu penting untuk analisis akademik terhadap kota dan budaya urban sejak munculnya pada abad ke-19 yang mencakup "representation of urban life and city-scapes in popular contemporary texts, such as film and real estate advertisements. It also considers some major city-building trends and discourses that have shaped the urban landscape."

Dalam tulisan-tulisan sebelumnya, isu infrastruktur dan ekonomi telah menjadi kajian menarik yang dibicarakan oleh beberapa penelitian. Wirakusuma (2014:49-50) misalnya, secara khusus mendalami persepsi wisatawan mancanegara dan menyimpulkan bahwa kunjungan wisatawan tidak hanya tergantung pada ketersediaan infrastruktur di Prawirotaman, akan tetapi juga ditentukan oleh kondisi psikografi para wisatawan, yaitu kesesuaian antara waktu libur mereka (winter holiday).

Tania, Ekomadyo, dan Zulkaidi (2018) juga menjelaskan bahwa Prawirotaman telah pula bertransformasi dari kampung turis menjadi kampung yang layak huni sebagai sebuah pengembangan perkotaan dengan ketersediaan infrastruktur yang mendukung. 
Masih mengenai infrastruktur, Ardhiansyah, Widyastuti, dan Septiari (2019:136) menjelaskan bahwa perubahan tata guna lahan telah mengakibatkan perubahan fungsi kampung Prawirotaman yang berimplikasi pada hilangnya karakteristik Kampung Prawirotaman sebagai Kampung Batik. Dahles dan Prabawa (2013:242) membahas isu peluang ekonomi dan menjelaskan bahwa tukang becak di Prawirotaman mendapat kesempatan dan peluang baru, "new opportunities in the tourism industry".

Terkait isu pendidikan, ada juga tulisan yang meneliti dua kampung tersebut. Hernadi (2020: 40-41) menyatakan bahwa kedua kampung tersebut telah berkontribusi pada peningkatan motivasi pelajar dalam belajar Bahasa Inggris.

Isu budaya juga telah banyak didiskusikan pada Kampung Prawirotaman dan Kampung Kauman. Nadrah Muhammad (2017: 180) menjelaskan bahwa ruang fisik kauman merupakan wujud nilai, hunian dan susunan ruang kampung yang memiliki bentuk dan konfigurasi khas yang menjadi elemen ruang yang disebut butulan dan jepitan yang dimaknai sebagai ruang pertalian yang dibentuk oleh konsep aksessibilitas, kekerabatan, sosialitas, dan teritorialitas yang berdimensi masa lalu. Selanjutnya Depari (2012:24-25) menjelaskan bahwa telah terjadi transformasi ruang Kampung Kauman yang merupakan sebuah produksinkretisme budaya.

Di sisi lain, Rianingrum, Sachari, dan Widodo (2014:29) menyatakan bahwa Kauman sebagai sebuah kampung wisata telah menjadi representasi nilai-nilai budaya Jawa yang harmonis pada manusia dan alam sekitarnya yang merupakan sebuah proses negosiasi yang berakibat pada munculnya ruang baru. Isu budaya juga didiskusikan dengan isu agama dan resistensi yang terjadi pada masyarakat Kampung Kauman dan Prawirotaman. Aktivitas mengaji yang dilakukan di pelataran Masjid Gedhe Kauman selama berlangsungnya sekatenan dijadikan ajang dakwah sebagai bentuk resistensi dari tradisi keraton yang dianggap sebuah kemusyrikan (Alam 2018).

Oleh karena itu tulisan ini dimaksudkan untuk mengisi ruang analisis mengenai identitas budaya perkotaan yang cenderung mengalami perubahan dilihat dari sisi pengaruh ideologi baru dari luar.

Dari tulisan-tulisan sebelumnya ditemukan bahwa isu dislokasi budaya yang dikaitkan dengan masuknya pengaruh ideologi luar, resistensi dan konflik di ruang baru absen dari pembicaraan. Tulisan ini menjadi penting karena dimaksudkan untuk mengisi kajian dislokasi identitas budaya tersebut dengan menggunakan pendekatan sosiologis yang membidik perubahan kehidupan masyarakat perkotaan. Menariknya ialah bahwa artikel ini menyuguhkan analisis dan pembahasan isu mengenai dislokasi budaya yang didasarkan pada data-data di lapangan yang diperoleh dengan pendekatan kualitatif dengan analisis sosiologis. Analisis data dengan menggunakan perspektif sosiologi, baik sosiologi perkotaan maupun sosiologi pedesaan merupakan sebuah kepaduan. Kedua kampung yang menjadi objek tulisan ini merupakan kampung yang berada di wilayah perkotaan yang masyarakatnya memiliki karakter pedesaan.

Hal yang menarik dikaji lebih lanjut adalah proses kedua kampung tersebut bertransformasi menjadi kampung turis dengan basis sosial budaya dan ekonomi yang berbeda. Proses terbentuknya kampung itu yang mungkin merupakan respons terhadap tekanan eksternal atau merupakan bentuk dari munculnya kesadaran 
baru masyarakat untuk menjadi bagian dari suatu perkembangan makro, dengan demikian, sangat urgen untuk menjadi pusat diskusi dalam tulisan ini. Sejarah dan kebudayaan masyarakat di kedua kampung dijadikan basis bagi transformasi dan menentukan keberhasilan kampung dalam mengkontekstualisasikan diri dalam perkembangan yang sedang berlangsung.

Oleh karena itu tulisan ini menjadi urgen karena ditulis berdasarkan hasil-hasil analisis atas pertanyaan-pertanyaan sosiologis yang sangat penting dalam menjawab tantangan zaman. Dengan menggunakan metode kualitatif, data hasil wawancara dengan tokoh masyarakat, tokoh pemuda dan tokoh agama di kedua kampung wisata tersebut yang berjumlah dua puluh tujuh orang dianalisis untuk menjawab pertanyaanpertanyaan penelitian yang diajukan. Selain itu, data-data yang penting juga didapatkan dari hasil observasi penulis selama hampir satu tahun dan didukung dengan data dokumen yang relevan.

Tulisan ini berpijak pada asumsi bahwa pengalaman dua kampung kota di Yogyakarta bertransformasi menjadi kampung turis telah melahirkan perubahan yang mendasar pada tataran sosial budaya masyarakat kota, yang mensyaratkan adanya penyesuaian-penyesuaian yang mendasar. Perubahan itu dapat ditemukan pada deligitimasi identitas kampung lama dan dislokasi kumunilitas yang menjadi inti pembahasan tulisan ini.

\section{Pengalaman Kampung Kauman dan Prawirotaman}

Kampung Kauman dan Kampung Prawirotaman dikenal oleh kebanyakan orang dengan berbagai sebutan, anggapan dan julukan (stereotype), baik dari kalangan warga kampung ter- sebut, maupun dari luar kampung. Hal ini berkaitan dengan latar historis, sosial budaya dan ekonomi yang pernah dan sementara berlangsung, bahkan merepresentasikan apa yang menjadi ekspektasi, kepercayaan, nilai dan makna yang diberikan dan dikonstruksikan oleh masyarakat terhadap kampung tersebut. Hadirnya kedua kampung ini dengan ciri khas masingmasing dapat mempengaruhi orang luar Yogayakarta atau pengunjung dalam mempersepsikan Kota Yogyakarta. Setidaknya, kedua kampung ini menghadirkan identitas yang membedakan dengan kampung-kampung lain di Yogyakarta. Hal-hal nampak dan berlangsung pada kedua kampung tersebut adalah suatu proses yang dinamis. Proses konstruksi dan kontestasi atas berbagai tatanan nilai-nilai sosial budaya, ekonomi dan religiusitas yang menjadi basis perilaku dan tindakan para warganya dalam merespons dan memaknai berbagai perubahan dan relasi sosial yang terus berlangsung. Proses konstruksi tersebut melahirkan berbagai penamaan atau sebutan terhadap kedua kampung ini.

\section{Kampung Kauman}

\section{Dikenal sebagai Kampung Batik}

Dari data yang terhimpun disebutkan bahwa aktivitas keseharian istri para penghulu di Keraton Yogyakarta adalah membatik, sambil mengurus rumah tangga mereka. Aktivitas membatik ini telah menjadikan Kampung Kauman yang merupakan tempat tinggalnya para penghulu sebagai sentra industri dan perdagangan batik saat itu. Alhasil kegiatan membatik menjadi sebuah tradisi di dalam lingkungan keraton atau kampung para penghulu atau pengurus agama (Islam). Abdurrachman (2000: 37) memaparkan bahwa desa pesantren dan khususnya desa 
pakuncen merupakan tempat tumbuhnya para pengrajin batik yang mempengaruhi kehidupan dan penghidupan masyarakat kota. Beberapa desa pakuncen yang dimaksud adalah makam kramat Sultan Agung Mataram, makam Panembahan Senapati, Sultan Pajang di Kota Gede, makam istri Sunan Kartasura di Nitikan, makam kyai Mulangi di Mlangi dan makam mertua Sultan Yogyakarta di Pakuncen.

Sementara itu Angelino (dalam Abdurrachman 2000:39) menunjukkan bahwa sekitar tahun 1927 terdapat 169 perusahaan batik di Yogyakarta yang tersebar di beberapa daerah, di antaranya; Kota Gede Solo (3 perusahaan), Kota Gede Yogyakarta (11 perusahaan), Prawirotaman (10 perusahaan), Karangkajen (14 perusahaan), Brantakusuman (5 perusahaan), Mantrirejon (11 perusahaan), Tugu (sebanyak 32 perusahaan), Kauman (26 perusahaan) dan tempat lain di dalam kota (57 perusahaan). Data tersebut mengindikasikan bahwa kegiatan membatik di Kampung Kauman secara khusus dan beberapa wilayah di sekitaran Kota Yogyakarta merupakan kegiatan ekonomi yang dominan saat itu.

Sebagai sentra batik, Kampung Kauman tidak hanya berkembang secara ekonomi, namun juga mengalami perkembangan sosial kependudukan karena masuknya para pekerja/buruh batik di Kauman yang berlangsung sejak usaha batik (batik handle) menjadi usaha pokok (industri kecil) di Kauman pada awal abad ke-20 (Darban 2000; Huda 2012; Narulita 2004). Bahkan usaha batik di Kauman menjadi salah satu faktor terbentuknya kelas sosial antara pemilik/ pengusaha batik dan pekerja. Meskipun sekarang usaha batik tidak lagi berjalan, namun sisa-sisa kejayaan dan status sosial masyarakat pemilik usaha tersebut masih terlihat dari bangunan rumah-rumah tempat tinggal mereka.

\section{Kampung Santri dan Kampung Muslim}

Dalam sejarahnya, Kampung Kauman memang diperuntukkan bagi kaum Muslim. Para penghulu (pengulu) yang ketika itu ditempatkan di kawasan Pengulon adalah para abdi dalem keraton bidang keagamaan. Mereka adalah para tokoh atau ahli agama (Islam) yang diberi tugas oleh raja/sultan untuk mengurusi bidang keagamaan sekaligus menjadi pengurus dan jamaah Masjid Gedhe yang sekarang terdapat di Kampung Kauman. Di samping mengurusi masjid dan urusan keagamaan lainnya, para penghulu juga mengembangkan pendidikan keagamaan melalui masjid dan musholla yang mereka bangun masing-masing dan menjadikan tempat tersebut sebagai pesantren mereka. Dengan keberadaan pesantren-pesantren tersebut, maka berdatangan warga kampung lainnya dari daerah sekitar Yogyakarta, bahkan ada yang berasal dari Sumatera dan Sulawesi serta Kalimantan untuk belajar agama (nyantri) di pesantren-pesantren tersebut. Para santri ini menetap di Kampung Kauman untuk mendapatkan pelajaran agama dari para kiai yang sekaligus para penghulu keraton. Maraknya para santri untuk menetap dan belajar agama di Kampung Kauman kemudian menjadikan kampung ini disebut sebagai "Kampung Santri" (Darban 1984).

Seiring perkembangan waktu dan sosial di Kampung Kauman, pertambahan jumlah penduduk, baik karena kelahiran maupun karena masuknya warga kampung lainnya sebagai buruh/pekerja industri batik yang umumnya adalah Islam, menjadikan Kampung ini ber- 
penduduk mayoritas beragama Islam (Aryanti 2015). Kondisi ini menjadikan kampung Kauman juga disebut sebagai "Kampung Muslim." Sebutan atau label ini tidak hanya berasal dari luar kampung tersebut, akan tetapi juga dari warga Kampung Kauman yang memberikan atau mengkonstruksikan dirinya sebagai "Kampung Muslim."

Kesadaran identitas keagamaan ini tidak hanya dibentuk oleh sejarah lahirnya kampung tersebut, akan tetapi juga atas kesadaran warga Kampung Kauman dalam berbagai kesamaan di antara mereka, dengan berbagai simbol dan ikon yang mereprsentasikan Islam di Kampung Kauman yang juga ikut andil dalam membangun identitas tersebut. Bahkan mereka dengan sadar dan sengaja mempertahankan dan membangun identitas Islam hingga sekarang ini dengan berbagai bentuk.

Mempertahankan dan membangun identitas keislaman sebagaimana dilakukan oleh warga Kampung Kauman tidak hanya dengan slogan dan simbol-simbol materi semata. Dalam praktek kehidupan keseharian, ciri dan identitas ke-Islaman berusaha dibangun dan konstruksikan melalui praktek beribadah dan bermuamalah (Kuntowijoyo 1991). Dalam beribadah, terutama dalam melaksanakan shalat lima waktu, warga Kampung Kauman berusaha melaksanakan secara berjamaah di masjid. Meskipun mereka sadar dengan berbagai kendala, akan tetapi atas prakarsa para Takmir Masjid Gedhe, maka dibuatlah "Gerakan Shalat berjamaah" yang mulai dideklarasikan sekitar bulan Februari 2017. Gerakan ini menurut para penggagas tidak saja dimaksudkan untuk mengajak para warga Kauman untuk menjalankan shalat wajib secara berjamaah akan tetapi juga sebagai upaya untuk menguatkan ukhuwah sesama warga kampung Kauman dan khususnya kaum Muslim pada umumnya.

Pada sisi lainnya, gerakan ini dilakukan untuk tetap menjaga dan membangun citra Kampung Kauman sebagai Kampung Muslim, atau kampung yang lahir sebagai kampung "penegak Agama Islam," (Nakamura 1983) yang kemudian juga dijuluki sebagai "Kampung Muhammadiyah atau kampung Islam" yang mengedepankan orientasi dan sikap hidup "Amar ma'rüf dan nahi munkar" (mengajak melaksanakan perintah kebaikan dan menjauhi perbuatan yang dilarang) (Aryanti 2015; Darban 2000). Pada konteks kekinian, warga Kampung Kauman tetap dengan orientasi hidup keseharian mereka berlandaskan agama Islam yang mengikuti organisasi keagamaan Muhammadiyah, dengan orientasi pendidikan yang lebih maksimal. Keberadaan sekolah-sekolah Muhammadiyah, mulai didirikannya kembali sekolah muballigh dan dibentuknya "Pedoman Hidup Islami (PHI)" menjadi bukti bagaiman nilai-nilai Islam tetap menjadi orientasi hidup mereka (Triatmodjo 2012). Bahkan mereka, meskipun tidak tertulis, berusaha mewarnai seluruh aktivitas kauman dan kegiatan di Masjid Gedhe dengan "Pengajian" sebagai susupan nilai-nilai Islam. Nilai-nilai inilah yang secara sadar dihidupkan dan dipertahankan oleh warga Kauman.

\section{Kampung Muhammadiyah}

Dari sisi lokasi fisiknya Kampung Kauman juga dikenal oleh orang luar sebagai kampung yang berada di wilayah Keraton Ngayogyakarta, atau kampung di mana Masjid Gedhe (Masjid Agung) berada. Dalam berbagai literatur juga di- 
sebutkan bahwa Kampung Kauman merupakan kampung para penghulu keraton (Kampung Pengulon) yang sengaja didirikan sebagai bagian dari pelaksanaan birokrasi kerajaan atau kesultanan pada masa itu (Chawari 2017:48-50; Darban 2000). Meskipun sekarang ini tidak lagi menjadi bagian dari birokrasi keraton secara formal, akan tetapi kehadiran pengulon dalam acara-acara ritual yang menjadi tradisi keraton masih tampak. Jadi, keberadaan kampung ini telah menjadi bagian dari eksistensi kesultanan Yogyakarta atau kesinambungan kerajaan Mataram Islam. Ini berarti bahwa Kampung Kauman merupakan representasi dari Kerajaan Islam Mataram secara umum, dan representasi Islam (Muhammadiyah) secara khusus di Yogyakarta.

Sebutan sebagai kampung "Muhammadiyah" dan kampung "Islam" disebutkan karena terkait dengan sejarah terbentuk dan berdirinya organisasi Islam Muhammadiyah di Kampung Kauman ini oleh KH. Ahmad Dahlan, seorang khatib Masjid Keraton (Masjid Gedhe) Yogyakarta, pada tanggal 18 November 1912 (Abdurrachman 2000; Nakamura 1983). Meskipun setahun sebelumnya telah didirikan sekolah "Muhammadiyah", namun keberadaan organisasi ini justru semakin memperkuat posisi dan gerakan pendidikan Muhammadiyah (Abdurrachman 2000). Hingga kini, Kampung Kauman masih diidentikkan sebagai Kampung Muhammadiyah dan Kampung Islam. Bukan saja lantaran sebagai tempat lahirnya Kampung Islam dan tempat lahirnya "Muhammadiyah," akan tetapi masyarakat kampung ini menunjukkan tradisi dan praktek Islam dan khususnya mengambil organisasi Muhammadiyah sebagai dasar dalam sendi-sendi kehidupan mereka. Selain itu, beberapa peninggalan bersejarah yang berafiliasi dengan Muhammadiyah hingga kini masih difungsikan oleh warga.

Jargon bahwa "Kauman adalah Muhammadiyah", "Muhammadiyah ya Kauman" menjadi populer. Ini adalah sebuah ungkapan yang biasa diucapkan oleh warga Kauman tentang hubungan antara Kauman dan Muhammadiyah. Bisa jadi bahasa ungkapan ini tampak atau kedengarannya berlebihan. Akan tetapi jika ditelusuri secara historis dan konteks kekinian, ternyata ungkapan tersebut benar adanya. Betapa tidak, lahirnya Muhammadiyah adalah sebuah upaya yang dilakukan oleh seorang tokoh reformis Islam Kauman saat itu yang merupakan tokoh warga Kauman.

\section{Kampung Pariwisata}

Meskipun Kampung Kauman banyak dikenal sebagai Kampung Islam dan Kampung Muhammadiyah, akan tetapi julukan atau sebutan ini tidak menyurutkan niat beberapa kelompok pemuda di Kampung Kauman menggagas menjadi salah satu kampung destinasi pariwisata (khususnya wisata religi). Wisata Kampung Kauman dikelola oleh Kelompok Sadar Wisata (Pokdarwis) "Saka Wisata" Kauman dengan pengurusnya warga masyarakat Kauman sendiri. Ada juga "Komunitas Blusukan Kampoeng Jogja." Kedua kelompok ini menjadikan berbagai bangunan bersejarah "Muhammadiyah" dan berbagai tradisi yang ada di Kauman dan sekitarnya menjadi Objek Daya Tarik Wisata (ODTW).

Gagasan ini tidak hanya lahir dari respons warga Kampung Kauman terhadap perkembangan kampung pariwisata di Kota Yogyakarta, akan tetapi juga didorong oleh kebijakan Pemerintah 
Kota Yogyakarta untuk mengembangkan daya tarik wisata lainnya yang berbeda dengan apa yang sudah ada sebelumnya. Jika melihat dari potensi yang ada, Kampung Kauman memiliki potensi untuk dikembangkan menjadi objek wisata religi karena memiliki berbagai bangunan peninggalan bersejarah yang berkaitan langsung dengan sejarah perkembangan Islam, khususnya perkembangan Muhammadiyah.

\section{Kampung Prawirotaman}

\section{Kampung Batik menjadi Kampung Bule}

Serupa dengan Kampung Kauman, Kampung Prawirotaman dulu juga dikenal sebagai Kampung Batik, meskipun ada perbedaan dalam jenis batik yang dikembangkannya. Jika Kampung Kauman dikenal dengan insdutri "batik handel", maka Kampung Prawirotaman terkenal dengan "batik cap" atau "batik stempel". Pesatnya perkembangan usaha batik di Prawirotaman cukup memberikan perubahan status sosial ekonomi masyarakat, terutama trah pendiri kampung tersebut. Secara ekonomi mereka mapan dengan usaha batik, hingga hampir seluruh usaha batik telah dikuasai oleh mereka. Selama kurang lebih sepuluh tahun, yaitu dari tahun 1960-1970-an usaha batik Prawirotaman mengalami perkembangan yang sangat pesat, hingga akhirnya mengalami kemunduran sekitar tahun 1970-an. Disebutkan oleh Sumintarsih dan Andrianto (2014) bahwa meredupnya usaha tenun dan batik karena tiga hal yaitu dicabutnya subdisi kain mori (putih) oleh pemerintah, pergeseran pemakaian kain batik dalam berbagai keperluan (keperluan adat, busana) dan membanjirnya batik dari luar seperti Cina yang lebih murah di pasaran.

Kondisi di mana industri batik merosot, tidak hanya menyebabkan terjadinya perubahan sosial ekonomi secara drastis di Kampung Prawirotaman, dan Yogyakarta secara umum, akan tetapi juga melahirkan berbagai divesifikasi atau strategi ekonomi baru dalam kehiduapn sosial masyarakat, khususnya di Kampung Prawirotaman. Para juragan batik yang gulung tikar beralih ke jenis usaha lainnya, seperti usaha penginapan atau hotel dan berbagai jenis usaha jasa lainnya untuk melayani para turis, khususnya bule yang datang ke kampung ini. Inilah awal kisah bagaimana Kampung Prawirotaman tidak hanya dilabeli oleh orang luar akan tetapi juga dikonstruksikan oleh warga masyarakatnya sendiri dengan julukan Kampung Internasional, Kampung Turis atau Kampung Bule.

\section{Kampung Turis}

Geliat pariwisata di Yogyakarta sepertinya memberikan ruang bagi setiap kampung di Kota Yogyakarta untuk mengembangkan dan membenahi dirinya menjadi kampung tujuan pariwisata. Namun berbeda dengan kampung lainya, Kampung Prawirotaman menjadi salah satu inspiriasi kampung lainnya dalam mengelola pariwisata berbasis kampung secara mandiri. Modal awal yang dimiliki oleh para pengusaha dalam bidang wisata di Kampung Prawirotaman cukup memadai. Rumah-rumah mereka yang luas dan permanen yang dulunya adalah rumah tempat usaha batik sangat memudahkan bagi mereka untuk menyulapnya menjadi penginapan, homestay dan bahkan menjadi hotel. Ketersediaan inilah yang dimanfaatkan oleh warga Kampung Prawirotaman, khususnya trah "Prawirotama" dalam mengembangkan usaha perhotelan dan penginapan. Adapun jumlah fasilitas dan infrastruktur pariwisata berupa hotel dan penginapan di Kampung Prawirotaman, sebagaimana hasil penelitian Sumintarsih dan Andrianto 
(2014), menunjukkan angka yang tinggi, yaitu 23 buah hotel, 17 buah guest-house, 4 buah homestay dan 3 buah wisma.

Ketersediaan berbagai hotel dan penginapan dengan ragam fasilitas dan harga terjangkau merupakan daya tarik tersendiri bagi para wisatawan mancanegara, khusunya turis dari eropa yang senang datang ke Kampung Prawirotaman. Tidak hanya untuk sekedar berkunjung, mereka juga menginap di kampung ini, khususnya di daerah Prawirotaman I. Tidak hanya karena ketersediaan hotel dan penginapan, akan tetapi di kampung ini para turis juga dimanjakan dengan adanya sederet artshop, kafe, toko buku, pasar tradisional, dan sebuah batu tulis yang menjadi daya tarik wisata alternatif (Utami dan Haryanto 2015; Utomo 2019). Hampir setiap hari dapat dijumpai turis luar negeri di Kampung Prawirotaman. Mereka senanguntuk menikmati kampung hilir mudik dengan berjalan kaki ataupun naik becak, secara perorangan, berpasangan dan berkelompok, keluar-masuk di hotel-hotel, penginapan, café dan resto yang tersedia, terutama menjelang sore hingga malam hari. Bahkan dalam kegiatan budaya yang diselenggarakan oleh warga Kampung Prawirotaman empat tahun terakhir ini, para turis asing juga turut ambil bagian di dalamnya, baik dalam acara kesenian maupun dalam pawai becak.

Kampung ini telah tumbuh menjadi kampung tanpa malam karena seakan tiada henti beraktivitas hingga malam hari. Fenomena ini lantas mendorong orang-orang sekitarnya, bahkan warga Kampung Prawirotaman sendiri, untuk menyebutnya sebagai Kampung Internasional. Tidak hanya banyaknya turis yang lalulalang di kampung ini lantas disebut sebagai kampung internasional, akan tetapi perilaku dalam berbahasa pun juga mengdindikasikan sebagai "Kampung International". Mereka umumnya menggunakan bahasa Inggris dalam berkomunikasi, baik oleh para penjaga dan pemilik coffee, art shop, tukang becak maupun penduduk sekitar (Anonim 2016). Fenomena perubahan sikap dan perilaku oleh warga Kampung Prawirotaman ini menunjukkan bahwa adanya proses deteritorialisasi budaya, yaitu budaya asing (eropa) ke Prawirotaman, terutama dalam aspek bahasa dan budaya material lainnya.

\section{Perubahan Lanscape dan Mindset}

Geliat pariwista yang terjadi di Kampung Kauman memang belum sesemarak sebagaimana kampung-kampung lainnya yang ada di Kota Yogyakarta, misalnya dengan Kampung Prawirotaman. Di samping respons masyarakatnya yang berbeda, juga karena potensi pengembangan pariwisata yang akan dikembangkan juga berbeda. Namun tidak berarti bahwa adanya rencana pengembangan pariwisata (wisata religi) di kampung ini tidak ada pro dan kontra dalam masyarakat.

Pada prinsipnya warga Kampung Kauman tidak keberatan dengan program pengembangan pariwisata tersebut, akan tetapi dijadikannya beberapa bangunan bersejarah sebagai Bangunan Cagar Budaya (BCB) di Kampung Kauman sebagai bagian paket wisata (misalnya Pengulon dan beberapa rumah juragan batik) menjadi problem tersendiri ketika bangunan-bangunan tersebut keasliannya harus dipertahankan sebagaimana benda peninggalan bersejarah lainnya. Penyebabnya adalah rumah-rumah tersebut adalah rumah kepemilikan pribadi yang sewaktu-waktu dapat 
direnovasi atau diubah oleh pemiliknya untuk menyesuaikan dengan kebutuhan internal rumah tangga bersangkutan sebagaimana telah banyak dilakukan pada rumah-rumah lainnya di Kampung Kauman. Namun pada saat yang sama, aturan Pemerintah telah mengatur pemanfaatan bangunan cagar budaya yang ada di Kota Yogyakarta yang tidak bisa diubah atau direnovasi yang sangat berbeda dengan bentuk aslinya.

Kebijakan penetapan benda cagar budaya di Kampung Kauman, memang tidak direspons secara frontal oleh warga, akan tetapi mereka melakukan perubahan fisik bangunan mereka secara diam-diam (tidak mengajukan permohonan izin ke Pemerintah Kota Yogyakarta). Perlawanan atau sikap kontra ini dilakukan untuk menyesuaikan bangunan rumah mereka dengan kebutuhan rumah tangga mereka yang secara demografi mengalami penambahan, selain untuk menciptakan suasana nyaman, bersih dan sehat dalam rumah mereka masing-masing. Justru yang mendapat respons keras dari warga adalah ketika ada upaya untuk menjadikan makam Nyi Ahmad Dahlan yang berada di sebelah barat Masjid Gedhe dibuka untuk wisata ziarah yang berkaitan dengan ngalap berkah (meminta kemurahan rezeki). Alasan penolakan ini karena semata-mata urusan keyakinan, bahwa wisata ziarah ke makam dianggap bertentangan dengan syari'at Islam, khususnya di kalangan Muhammadiyah. Wisata ziarah ke makam Nyi Ahmad Dahlan hanya diperbolehkan jika berkaitan dengan ketokohan dan perjuangannya.

Pro dan konra juga muncul, meskipun tidak tampak di permukaan. Pertentangan itu terkait dengan tata nilai dalam berbusana dan berperilaku. Mereka berusaha mengatur tata berbusana tersebut dengan memberikan peringatan atau pemberitahuan kepada siapa saja yang melanggar tata kesopanan ketika masuk ke Kampung Kauman.

Perubahan yang berlangsung di Prawirotaman tidak menunjukkan sikap penolakan atau kontra secara mendasar di kampung tersebut. Sebaliknya mereka cenderung mengikuti arus perubahan itu. Ini terlihat dari semakin maraknya perubahan fisik yang terjadi. Beberapa bangunan lama direnovasi dengan mengubah bentuk awalnya dari bentuk rumah tinggal menjadi model café atau resto sebagaimana bentuk bangunan lainnya yang sudah ada, terutama di sepanjang Jl. Prawirotaman I dan Prawirotaman II (Jl. Gerilya). Khususnya di Jl. Prawirotaman III, memang tidak banyak terjadi perubahan bangunan rumah menjadi café atau resto. Bangunan rumah tinggal masih tampak banyak yang bertahan. Kemungkinan ini bisa saja terjadi sebab kawasan Prawirotaman I dan II memang sejak dari awal menjadi kawasan perkembangan kampung turist, selain jalan yang ada cukup luas sehingga mendukung perkembangan tersebut

Jika mencermati perkembangan masyarakat di Prawirotaman I dan II fenomena perubahan fisik bangunan, memang semakin marak mengkuti perkembangan pariwisata di Yogyakarta, hingga sebagian warga merasa semakin sempitnya ruang gerak mereka, karena fenomena semakin terbatasnya ruang publik (Lefebvre 1991; Low 1996; Simonsen 1996). Ekspansi pembangunan fisik di Prawirotaman menimbulkan rasa prihatin dan cemas di kalangan warga Prawirotaman yang kemudian ditunjukkan dengan perhelatan yang dinamai "Car Free Night ke-4 dalam tema "Rindu Ruang". Acara ini akan yang dilakukan setiap tahunnya (lihat: GudegNet 
2016). Kegiatan tersebut ingin mengekspresikan rasa kekhawatiran terhadap semakin sempitnya ruang publik sekaligus kerinduan adanya ruang terbuka yang dulu pernah dinikmati dan sekarang berubah menjadi bangunan-bangunan hotel dan kafe yang sangat ramai. Kegiatan ini meskipun tidak dilakukan sebagai wujud protes atau penolakan terhadap berbagai perubahan fisik di Prawirotaman, akan tetapi setidaknya memberikan kesadaran kepada warga betapa pentingnya ruang terbuka bagi mereka, sekaligus mengisyaratkan perlunya mengurangi atau membatasi penambahan atau perubahan ruangruang kosong yang ada untuk bangunan fisik.

\section{Perubahan Fisik Kampung dan Redefinisi Identitas}

Kampung Kauman bagi warganya bukan sekedar tempat tinggal biasa sebagaimana halnya dengan kampung-kampung pemukiman pada umumnya, akan tetapi Kampung Kauman direpresentasikan sebagai sesuatu yang mencirikan identitas warganya, yaitu sebagai kampung Islam atau Kampung Muhammadiyah. Mereka menyebutnya sebagai Kampung Islam karena secara fisik terdapat Masjid Gedhe dan beberapa mushollah atau langgar dan sekolah Islam yang merupakan peninggalan Muhammadiyah.

Seiring perkembangan waktu, meskipun tidak banyak mengalami perubahan fisik secara mendasar di kampung ini, akan tetapi hadirnya paket atau program pariwisata berbasis peninggalan Islam (Muhammadiyah) sedikit mengubah pencitraan atas kampung dan identitas mereka. Meskipun mereka dalam mempromosikan Kampung Kauman sebagai kampung pariwisata, akan tetapi esensi dari apa yang dikemas dan dipromosikan tersebut adalah mereka ingin dikenal sebagai "Kampung Kauman Darussalam" (kampung Islam yang terbuka dan damai). Hal in isangat bertolak belakang dengan pencitraan atau sebutan yang sering dilekatkan oleh orang-orang lain kepadanya sebelumnya (bisa jadi counter) yaitu sebagai kampung yang eklusif dan tertutup dan merupakan kampung preman. Oleh karena itu, rutinitas yang mereka lakukan harus lebih islami, salah satunya kegiatan mengaji bagi anakanak, remaja dan orang dewasa juga diatur sebagaimana jadwal belajar di kampung-kampung pada umumnya.

Dulunya rumah-rumah yang besar dan mewah dengan arsitektur Jawa, serta hadirnya batik cap yang dihasilkan merupakan ciri atau penanda bagi warga Kampung Prawirotaman. Sebagai penanda dalam pengertian di sini adalah warga Kampung Kauman terkenal dan dikenal sebagai Kampung Batik Cap. Di sini, rumahrumah besar juragan batik, dan batik yang diproduksi merupakan simbol atau penanda fisik yang merepresentasikan identitas diri warga Kampung Prawirotaman. Sekarang, dengan berubahnya beberapa rumah-rumah para juragan batik menjadi hotel-hotel, adanya kafe, resto dengan berbagai jenis kuliner asing beserta banyaknya turis asing berseliweran dan menginap di Kampung Prawirotaman (Wardhana 2016) menjadikan kampung ini dikenal dan disebut oleh warga Prawirotaman sendiri sebagai Kampung Turis, Kampung Bule atau Kampung Internasional.

\section{Pariwisata dan Perubahan Sosial}

Dulu ada dua model relasi yang terbentuk dan terjalin di Kampung Kauman, yaitu relasi antara para pengulu (abdi dalem keraton bidang 
keagamaan) dengan keraton (Sultan), relasi antara para pengusaha batik dengan buruh/ pekerja batik, serta relasi antara para pengulu dengan santri. Relasi yang terbentuk merupakan relasi yang cenderung bersifat vertical. Sekarang relasi cenderung bersifat horizontal, yaitu relasi antara sesama warga kampung Kauman yang Muslim atau sesama Muhammadiyah atau relasi antara afiliasi partai. Model hubungan ini terbangun secara egaliter. Hal ini bisa terjadi karena dalam paham Muhammadiyah prinsip kebersamaan atau kesetaraan derajat menjadi basis hubungan antara mereka. Fenomena ini memang bukan serta merta pengaruh dari munculnya program pariwisata di Kampung Kauman, akan tetapi jauh sebelumnya, yaitu lahirnya Muhammadiyah menjadi sumber utama perubahan bentuk relasi tersebut. Tidak berarti tidak ada relasi sosial baru yang muncul, sebab adanya kelompok pemandu wisata dari dalan dan dari luar Kauman, akan membentuk relasi sosial baru antara sesama pemandu, antara para pemandu dengan warga Kauman, relasi antara pemandu dengan para wisatawaan dan juga relasi antara wisatawan dengan warga Kampung Kauman yang kesemuanya merupakan relasi yang bersifat horizontal.

Masuknya turisme di Kampung Kauman memang belum banyak mengubah tatanan sosial yang ada, termasuk munculnya relasi atas segregasi sosial atas dasar kelas sosial dan pekerjaan. Dalam konteks bahwa ada gejala munculnya kelompok baru yaitu pegiat pariwisata memang demikian adanya, meskipun tidak seluruh kelompok pegiat pariwisata Kauman adalah warga kauman sendiri, tetapi beberapa adalah dari luar Kauman. Misalnya kelompok pegiat "Saka Wisata” yang dikelola oleh
Remaja Masjid Gedhe Kauman di bawah koordinasi Takmir Masjid, sedangkan yang dari luar adalah "Komunitas Blusukan". Beberapa rumah yang telah diubah menjadi homestay di Kauman, juga belum menunjukkan gejala baru sebagai kelompok atau kelas sosial baru, kecuali sebelumnya adalah mereka memang menjadi kelas sosial tinggi saat industri batik masih jaya.

Pariwisata di Kampung Kauman belum melahirkan kelas sosial baru yang berimplikasi pada munculnya model relasi sosial yang baru yang bersifat vertikal. Sebaliknya, di Kampung Prawirotaman justru tampak sekali perbedaan sosial tersebut. Relasi sosial secara vertikal terbentuk antara warga Kampung Prawirotaman yang bekerja di hotel-hotel, kafe, resto dengan pemilik hotel-hotel tersebut, termasuk dengan tukang becak yang mencari keuntungan dari memberi informasi atau mempromosikan hotel. Demikian pula terbentuk relasi horizontal antara sesama pemilik hotel, pemilik kafe dan resto, serta antara para turis dengan warga. Relasi horizontal juga terbentuk diantara sesama warga Kampung Prawirotaman yang memiliki rumah homestay, antara sesama tukang becak dan antara sesama pemilik warung. Jadi fenomena turisme di Kampung Prawirotaman menunjukkan begitu banyaknya diversifikasi aktivitas ekonomi atau pekerjaan yang secara langsung juga dapat melahirkan kelas-kelas dan relasi sosial yang baru, baik yang bersifat vertikal maupun relasi sosial yang bersifat horizontal.

\section{Implikasi Sosial atas Perubahan Relasi}

Jauh sebelum adanya program pariwisata di Kampung Kauman, yaitu saat berdirinya Muhammadiyah 1922 dan lahirnya kebijakan pemekaran 
Kampung Kauman menjadi beberapa RW berdasarkan Permendagri No. 7/1983 merupakan salah satu cikal bakal terjadinya perubahan relasi sosial secara mendasar.

Adanya pariwisata berbasis religi di Kampung Kauman, tampaknya tidak banyak mengubah pola relasi sosial yang ada, meskipun muncul pola relasi yang baru, yaitu relasi personal antara pemandu wisata dengan para pengunjung, antara pengunjung dengan warga dan antara warga Kampung Kauman sendiri. Relasi yang terbentuk ini nampaknya masih bersifat sementara saja dan lebih bersifat relasi ekonomi semata terutama antara para warga Kauman dengan para wisatawan dan antara warga Kauman dengan para pemandu atau pelaku wisata. Hal ini disebabkan oleh belum mapannya manajemen dan program wisata di Kampung ini, dan masih bersifat temporal. Meskipun demikian dengan semakin marak dan intensifnya pengembangan pariwisata di Yogyakarta khususnya di Kampung Kauman, akan memberikan ruang semakin intensif dan terbukanya relasi sosial antara warga Kampung Kauman dengan para pengunjung, dan secara internal di Kampung kauman itu sendiri.

Meskipun model relasi sosial yang berifat komunal ada, akan tetapi tidak begitu kuat dibandingkan dengan model relasi sosial yang bersifat individual. Relasi komunal kecenderungannya hanya berlangsung pada situasi dan momen tertentu yang hanya berlangsung sekali setahun, yaitu dalam kegiatan perayaan hari kemerdekaan dan pada saat pelaksanaan festival seni budaya, selebihnya dalam kehidupan keseharian, relasi individual lebih menonjol. Relasi ini terbentuk atas dasar bidang kerja yang digeluti masing-masing. Menyurutnya nilai-nilai komunal ini tidak lain disebabkan oleh aktivitas keseharian mereka yang begitu padat yang tertuju pada kebutuhan personal. Nilai rupiah dan dollar di Kampung ini sangat berharga sehingga prinsip keuntungan juga menjadi prioritas. Aktivitas ekonomi yang lahir sebagai respons terhadap maraknya pariwisata semakin pesat. Bagi mereka yang punya rumah dimanfaatkan sebagai homestay, penginapan atau untuk menjual berbagai kebutuhan pariwisata lainnya. Tidak jarang pula ada yang menyewakan rumah dan tempat mereka untuk berusaha, bahkan hingga ada yang menjualnya karena tergiur oleh keuntungan secara ekonomi. Ini menunjukkan betapa pariwisata di Kampung Prawirotaman banyak mengubah tatanan dan relasi sosial yang dulunya relasi komunal menjadi sebuah relasi yang lebih bersifat profesional dan cenderung personal/ individual berdasarkan kepentingan ekonomi.

\section{Akibat yang Muncul Atas Perubahan Relasi Sosial}

Akibat negatif yang muncul atas perubahan sosial di Kampung Kauman memang belum menampakkan disharmoni sosial secara mendasar. Meskipun demikian, memang ada saling curiga atau gossip berkenaan dengan adanya paket pariwisata yang menjadikan kuburan Nyi Ahmad Dahlan dan beberapa kuburan lainnya di belakang Masjid Gedhe sebagai salah satu Objek Daya Tarik Wisata (ODTW). Namun hal ini tidak meluas sebab kecurigaan ini hanya ditujukan kepada satu orang saja yang kebetulan salah satu tokoh masyarakat di Kampung Kauman, dan yang bersangkutan menjelaskan secara detail apa yang menjadi tujuan dari program tersebut. Secara 
eksternal juga ada disharmoni antara warga Kampung Kauman dengan salah satu pengelola paket wisata yang ada. Disharmoni ini muncul karena adanya bentuk penolakan terhadap program atau paket pariwisata yang dikelola secara mandiri dan oleh beberapa kelompok pegiat pariwisata, misalnya oleh Komunitas Blusukan Yogyakarta. Menurut warga yang ditolak bukan karena program pariwisatanya tersebut akan tetapi karena model penegelolaannya yang tidak partisipatif. Warga Kampung Kauman berharap bahwa dalam setiap paket pariwisata yang dikemas dan akan dilakukan di Kampung Kauman, seharusnya warga kampung tersebut dilibatkan, setidaknya dalam penyediaan konsumsi. Hal ini dimaksudkan agar warga merasa mendapat untung atau menjadi bagian dari paket pariwisata tersebut.

Khususnya di Prawirotaman, munculnya kecenderungan relasi personal atas profesi atau ketrampilan kerja, serta stratifikasi sosial yang berdasarkan profesi tersebut pada prinsipnya melahirkan jarak sosial yang semakin renggang, terutama bagi para pelaku pariwisata (pemilik hotel, penginapan, kafe dan para pemilik usaha wisata lainnya dengan masyarakat sekitarnya. Ini terjadi lantaran kedua kubu antara pemilik modal (kelas menengah yang sebagian besar warga dari luar dan beberapa dari Prawirotaman) dengan warga Kampung Prawirotaman secara umum (pekerja di usaha pariwisata dan warga kampung biasa) tidak lagi memiliki kesempatan untuk berkumpul secara intensif. Mereka yang memiliki usaha sibuk dengan urusannya masing-masing ketimbang membangun hubungan-hubungan sosial yang intensif di Kampung. Pada sisi yang lainnya, warga kampung hanya bisa menjadi penonton yang pasif dengan maraknya roda ekonomi yang menyebabkan ruang-ruang fisik berupa ruang terbuka semakin sempit lantaran dibangunnya berbagai fasilitas pariwisata berupa hotel, penginapan dan kafe-kafe. Khusus keberadaan beberapa kafe di Prawirotaman lokasinya dibatasi oleh warga dengan berbagai pertimbangan keamanan dan dampak polusi suara serta dampak sosial bagi remaja. Menurut warga Prawirotaman, kafe hanya dibolehkan di pinggir jalan besar, sedangkan di bagian dalam Kampung tidak dibolehkan oleh warga.

\section{Kesimpulan}

Kampung Kauman dan Kampung Prawirotaman adalah dua di antara sekian banyak kampung kota yang memberikan corak dan dinamika kehidupan sosial budaya dan ekonomi di Kota Yogyakarta, tidak hanya pada periode masa lalu namun juga pada konteks kekinian. Oleh komunitasnya masing-masing, kedua kampung ini dimaknai dan dikonstruksikan sebagai suatu ruang fisik yang mereprsentasikan suatu identitas sosial budaya dan ekspektasi dari para pemilik atau penghuninya. Pada saat yang sama proses kontestasi atas nilai-nilai yang dilekatkan (disematkan) juga terus bergulir, baik secara internal di dalam kedua kampung ini, maupun secara eksternal dengan berbagai kampung di sekitarnya. Waktu dulu dan waktu kekinian bisa jadi meghasilkan suatu identitas yang tidak sekedar hasil dari suatu proses dialektika ruang dan waktu, namun juga adalah hasil dari proses sosialbudaya yang berlangsung di dalamnya. Masa lalu bagi kedua kampung ini, terutama Kampung Kauman dengan identitas keislamannya diupayakan untuk dihadirkan kembali (rekonstruksi), meskipun dengan bentuk dan wujud yang berbeda dari sebelumnya. Sebalik- 
nya, yang dipertahankan dan tetap dihadirkan di dalam kampung Prawirotaman adalah struktur dan kelas sosial dari trah "Prawirotama" yang mapan secara ekonomi. Ketika usaha batik mengalami kemerosotan di Kampung Prawirotaman, maka usaha penginapan dan usaha wisata lainnya dikembangkan maka dengan sendirinya terjadi dinamika dan perubahan struktur dan kultur dalam kehidupan sosial di kampung ini.

Konstruksi sosial adalah suatu proses dinamis, suatu proses yang terus bergulir seiring perubahan waktu, ruang dan konteks sosial budaya, ekonomi dan politik. Setiap kelompok masyarakat atau komunitas manapun akan mengalami dan berhadapan dengan proses-proses tersebut, tak terkeculi di Kampung Kauman dan Kampung Prawirotaman. Apa yang berlangsung di Kampung Kauman dan Kampung Prawirotaman sebagaimana dipaparkan di atas mengindikasikan adanya dinamika dan perubahan struktur sosial masyarakat Kota Yogyakarta secara umum, dan secara khusus di kedua kampung tersebut. Kampung Kauman dan Kampung Prawirotaman sebagai ruang fisik yang secara administrasi pemerintahan memiliki batas-batas tertentu pada dasarnya merepresentasikan suatu identitas sosial masyarakat yang ada di dalamnya atau warga masyarakat yang merasa memiliki dan menjadi bagian darinya.

Kampung Muslim dan Kampung Pariwisata Religi sebagaimana dikonstruksikan oleh warganya terhadap Kampung Kauman akan menghadirkan identitas keislaman dalam sikap, praktek dan materi pendukung yang mereprsentasikan identitas keislaman tersebut. Demikian halnya Kampung Prawirotaman dengan perilaku dan praktek berbahasa, ketersediaan sarana dan prasarana pariwisata menunjukkan bahwa warga kampung ini mengkonstruksikan kampung sebagai Kampung Turis.

Namun demikian, hal mendasar yang dapat disimpulkan dari proses-proses sosial yang berlangsung di Kampung Kauman dan Kampung Prawirotaman adalah, pertama, bahwa prosesproses tersebut adalah suatu proses sosial yang secara sadar dilakukan oleh warga masyarakat kedua kampung ini dalam merespon dinamika dan perubahan yang berlangsung di Kota Yogyakarta. Kedua, proses-proses ini, meskipun adalah suatu proses sosial, akan tetapi ruang fisik terutama di Kampung Prawirotaman diupayakan merepresentasikan apa yang menjadi ekspektasi masyarakatnya. Sebaliknya, di kampung Kauman, identitas keislaman yang dimaksudkan lebih mengedepankan tatanan sikap, dan perilaku ketimbang materi/benda. Ketiga, proses-proses ini menghasilan suatu dinamika dan transfomasi struktur dan kultur masyarakat yang kemudian menghasilkan suatu model relasi sosial ekonomi dan politik yang berbeda pula.]

\section{Daftar Pustaka}

Abdurrachman, Surjomihardjo. 2000. Kota Yogyakarta, 1880-1930: Sejarah Perkembangan Sosial. Ed. A. Setiono dan A. Samhuri. Yogyakarta: Yayasan Untuk Indonesia.

Alam, Lukis. 2018. "Popular Piety and the Muslim Middle Class Bourgeoisie in Indonesia." AlAlbab 7(2):237.

Anonim. 2016. "Kampung Prawirotaman, Rumah Kedua Bule-Bule di Jogja yang Sudah Populer di Manca." Yogyalagi.com. Diambil (http://www.yogyalagi.com/2016/03/ka 
mpung-prawirotaman-rumah-keduabule.html).

Ardhiansyah, Nino, Dhyah Ayu Retno Widyastuti, dan Elisabet Dita Septiari. 2019. "Perubahan Tata Guna Lahan Kampung Prawirotaman Kota Yogyakarta sebagai Dampak Keberadaan Kawasan Komersial." Arteks: Jurnal Teknik Arsitektur 3(2):149-58.

Aryanti, Tutin. 2015. "Branding the Islamic Village: Modesty and Identity in Yogyakarta Kauman Village, Indonesia." pp. 12634 in Procedia - Social and Behavioral Sciences. Vol. 184. Elsevier B.V.

Chawari, Muhammad. 2017. "Data Baru tentang Kampung Kauman Yogyakarta Studi Berdasarkan Temuan Artefaktual." Berkala Arkeologi37(2):181-94.

Dahles, Heidi dan Titi Susilowati Prabawa. 2013. "Entrepreneurship In The Informal Sector. The Case of the Pedicab Drivers of Yogyakarta, Indonesia." Journal of Small Business \& Entrepreneurship 26(3):241-59.

Darban, Ahmad Adaby. 1984. "Kampung Kauman: Sebuah Tipologi Kampung Santri di Perkotaan Jawa (Studi Perbandingan Sejarah Pertumbuhan Kampung Kauman Kudus dan Yogyakarta)." Universitas Gadjah Mada, Yogyakarta.

Darban, Ahmad Adaby. 2000. Sejarah Kauman: Menguak Identitas Kampung Muhammadiyah. Yogyakarta: Tarawang.

Depari, Catharina Dwi Astuti. 2012. “Transformasi Ruang Kampung Kauman Yogyakarta sebagai Produk Sinkretisme Budaya." Jurnal Arsitektur Komposisi 10(1):11-26.

GudegNet. 2016. "Rindu Ruang: Prawirotaman Car Free Night Yogya." GudegNet. Diambil (https://www.gudeg.net/hiburan- 2/3808/rindu-ruang--prawirotaman-carfree-night.html).

Hernadi, Nour Ardiansyah. 2020. "Prawirotaman as Kampung Inggris and the Improvement of Students Motivation in Learning English for Tourism Students In Yogyakarta." Kepariwisataan:Jurnal Ilmiah 14(1):37-44.

Hill, Kate. 1999. "Thoroughly Imbued with the Spirit of Ancient Greece: Symbolism and Space inVictorian Civic Culture." dalam Gender, Civic Culture and Consumerism: Middle Class Identity in Britain 1800-1940, Ed. A. Kidd dan D. Nicholls. Manchester: Manchester University Press.

Huda, Lailatul. 2012. "Wanita Kauman Pengrajin Batik Kesultanan Yogyakarta 1900-1930." Al-Manar 6(2):1-18.

Hutama, Irsyad Adhi Waskita. 2016. "Exploring the Sense of Place of an Urban Through the Daily Activities, Configuration of Space and Dweller's Perception: Case Study of Kampung Code, Yogyakarta." University of Twente Netherlands.

Kuntowijoyo. 1991. Paradigma Islam. Bandung: Mizan.

Lefebvre, Henri. 1991. The Production of Space. Ed. D. Nicholson-Smith. Cambridge: Basil Blackwell.

Low, Setha M. 1996. "Spatializing Culture: The Social Production and Social Construction of Public Space in Costa Rica." American Ethnologist 23(4):861-79.

Muhammad, Nadrah. 2017. "Butulan dan Jepitan sebagai Ruang Liminal dalam Budaya Jawa Islam di Perkampungan Kauman Yogjakarta." Etnohistori: Jurnal Ilmiah Kebudayaan dan Kesejarahan 4(2):179-90.

Nakamura, Mitsuo. 1983. Bulan Sabit Muncul dari Balik Pohon Beringin: Studi tentang Per- 
gerakan Muhammadiyah di Kotagede Yogyakarta. Yogyakarta: Gadjah Mada University Press.

Narulita, Siska. 2004. "Sejarah Koperasi Batik PPBI Yogyakarta 1950-1980." Universitas Gadjah Mada Yogyakarta.

Nas, Peter J. M., Marlies de Groot, dan Michelle Schut. 2011. "Introduction: Variety of Symbols." pp. 7-25 dalam Cities Full of Symbols: A Theory of Urban Space and Culture, Ed. P. J. M. Nas. Leiden: Leiden University Press.

Rianingrum, Cama Juli, Agus Sachari, dan Pribadi Widodo. 2014. "Tradition Concept in Kauman Yogyakarta Settlement as a Representation of Javanese Cultural Values." Arts and Design Studies 14.

Sativa, Sativa. 2012. "Konsep Teritori Kampung Kauman Yograkarta." Inersia 8(2):110-16.

Simonsen, Kirsten. 1996. "What Kind of Space in What Kind of Social Theory?" Progress in Human Geography 20(4):494-512.

Stevenson, Deborah. 2003. Cities and Urban Cultures. Philadelphia: Open University Press.

Sullivan, John. 1986. "Kampung and State: The Role of Government in the Development of Urban Community in Yogyakarta." Indonesia (41):63-88.
Sumintarsih dan Ambar Andrianto. 2014. Dinamika Kampung Kota Prawirotaman dalam Perspektif Sejarah dan Budaya. Yogyakarta: Balai Pelestarian Nilai Budaya (BPNB) Yogyakarta.

Tania, Devi Johana, Agus Suharjono Ekomadyo, dan Denny Zulkaidi. 2018. "Transformasi Kampung Turis Menjadi Kampung Wisata Studi Kasus: Prawirotaman Yogyakarta." in Prosiding Seminar Kota Layak Huni/Livable Space.

Triatmodjo, Suastiwi. 2012. "Dua Ragam Makna pada 'Ruang dari Masa Lalu' di Permukiman Kauman Yogyakarta." Tsaqafa: Jurnal Kajian Seni Budaya Islam 1(1):1937.

Utami, Aulia Nastiti dan Ragil Haryanto. 2015. Kajian Keterkaitan Usaha Pendukung Akomodasi dengan Penginapan. Vol. 4.

Utomo, Yunanto Wiji. 2019. "Prawirotaman: Kampung Batik dan Penginapan yang Mendunia." Yogyes.com, September 16.

Wardhana, Retno. 2016. "Kampung Prawirotaman, Yogya Rasa Bali." travel.detik.com, Desember 6.

Wirakusuma, Reiza Miftah. 2014. "Analisis Karakter Wisatawan Mancanegara terhadap Fasilitas Wisata Kawasan Prawirotaman." Jurnal Pariwisata 1(1):42-51. 